\title{
The Effect Of Job Satisfaction And Organizational Commitment On Turnover Intention With Person Organization Fit As Moderator Variable
}

\author{
Eko Nur Pratama ${ }^{1}$, Emi Suwarni $^{2}$, Maidiana Astuti Handayani ${ }^{3}$ \\ Manajemen, Universitas Teknokrat Indonesia ${ }^{1,2,3}$ \\ JI. H.ZA Pagaralam, No 9-11, Labuhanratu,Bandarlampung ${ }^{1,2,3}$ \\ e-mail: ekonurpratama16@gmail.com ${ }^{1}$,emisuwarni@teknokrat.ac.id ${ }^{2}$, \\ maidiana astuti@teknokrat.ac.id ${ }^{3}$
}

To cite this document :

Pratama, N.E., \& Suwarni, E., Handayani, A.M. (2022). The Effect Of Job Satisfaction And Organizational Commitment On Turnover Intention With Person Organization Fit As Moderator Variable. Aptisi Transactions on Management (ATM), 6(1), 74-81.

DOI :

https://doi.org/10.33050/atm.v6i1.1722

\section{Abstract}

This study aims to examine and analyze the effect of job satisfaction and organizational commitment on turnover intention with person organization fit as a moderating variable on employees of PT Febri Dharma Mandiri. This research is a descriptive research with a quantitative approach. In this study, data were collected using a questionnaire as many as 123 respondents. By reducing the outlier data, the amount of data that can be processed is 109 data. Data analysis used multiple linear regression analysis and Moderated Regression Anlysis (MRA). The results of multiple linear regression analysis show that job satisfaction and organizational commitment partially have a negative and significant effect on turnover intention. Moderated Regression Analysis (MRA) shows that Person organization fit is not able to moderate job satisfaction on turnover intention, while Person organization fit is able to moderate organizational commitment to turnover intention. This study aims to determine the effect of job satisfaction and organizational commitment on turnover intention with person organization fit as a moderating variable on employees of PT Febri Dharma Mandiri. Respondents in this study amounted to 123 employees and data that can be processed amounted to 109 data. Based on the data that has been collected and the tests that have been carried out on the problem using multiple linear regression models and MRA (Moderated Regression Anlysis).

Keywords: job satisfaction, organizational commitment, Person organization fit, turnover intention

\section{Introduction}

Human resources are a determinant of the success of a company in achieving its goals. Every business that is run always requires entrepreneurs to be able to try and try to stay afloat from competition and the changes that will occur. Every company in running a business cannot escape attention to the management of human resources who are looking for. Problems related to human resources are decisive for a company's business and success in achieving goals, because goals will be achieved if employees carry out their work well [1].

In an organization or company, it is never separated from the condition of employee turnover (turnover intention). Turnover can also be referred to as the movement of labor to leave the organization. In addition, turnover also refers to how many employees leave the organization in a certain period [2]. Nasution [3], one must be able to see something that can affect the organization, namely employee turnover and entry, employee turnover can have a positive impact, but most changes have a good influence on the organization. Therefore, it is 
important for the company to pay attention to every possible factor that can affect the employee's desire to leave the company.

Job satisfaction is an important reason for employees to stay or leave the company or organization. Because the cause of turnover intention is employee job satisfaction. And to reduce the occurrence of turnover intention in the company, the company must at least increase the level of employee job satisfaction. Where job satisfaction is something that is individual and each individual has a different level of satisfaction the value system that applies to him [4]. Lestari and Mujiati [5], Job satisfaction itself is an emotional attitude in the form of love and a sense of fun towards his work, where this attitude is reflected in behaviors such as work morale, discipline, and work performance.

Agus [6] say that an increase in organizational commitment can be associated with an increase in productivity and a lower turnover intention. An attitude of commitment will appear in employees, if employees are satisfied with what is received in the company and is a form of loyalty to the company by always providing the best for the progress and goals of the company. One way that can be done to minimize the desire of employees to leave the company is to ensure compatibility between the organization and employees [7]. An understanding of PersonOrganization Fit (P-O Fit) can help companies select employees with values and beliefs that match the organization and can shape experiences that can strengthen that fit, because P-O Fit can maintain a flexible and committed workforce.

The results of research by Parwita [8], in their research entitled the effect of job satisfaction and organizational commitment on turnover intention (at CV Dwi Boga Utama) shows that job satisfaction and organizational commitment have a negative and significant influence on turnover intention. located at CV Dwi Catering Utama, Denpasar. Meanwhile, research by Yuda and Ardana [9], entitled the effect of job satisfaction and job stress on turnover intention of holiday inn express hotel employees, it shows that researchers have not succeeded in proving the relationship between job satisfaction and turnover intention.

From some of the previous studies above, it can be concluded that previous researchers showed that job satisfaction had a significant negative effect on turnover intention and there were also researchers who showed the results of their research that job satisfaction had no effect on turnover intention. If we add information obtained from observations at PT Febri dharma Mandiri, in the period 2018-2019 there is a turnover that exceeds $10 \%$, Adhi Prabowo[10], that the normal turnover rate is around $5 \%-10 \%$ of the total number of employees, while is said to be high if the turnover rate reaches $10 \%$ or more.

For the province of Lampung, PT Febri Dharma Mandiri cooperates with Abdoel Moeloek Hospital for the use of outsourced employee services in the field of cleanliness. With the start of the contract in 2018, due to work ties with employees using the outsourcing contract system, this has led to decreased job satisfaction and employee commitment due to concerns with work contracts. This has led to an increase in the number of employees who have left the company since 2018.

Table 1

Turnover PT Febri dharma mandiri in 2018-2020

\begin{tabular}{|c|c|c|c|}
\hline Year & $\begin{array}{c}\text { Number of } \\
\text { employees }\end{array}$ & $\begin{array}{c}\text { Number of } \\
\text { Employees } \\
\text { Leave }\end{array}$ & $\begin{array}{c}\text { Turnover } \\
\text { Percentage }\end{array}$ \\
\hline 2018 & 134 & 14 & $11 \%$ \\
\hline 2019 & 164 & 19 & $12 \%$ \\
\hline 2020 & 178 & 10 & $6 \%$ \\
\hline
\end{tabular}

Additional information obtained from the supervisor of PT Febri Dharma Mandiri, in 2020 PT Febri Dharma Mandiri changed the organizational structure and regulations to improve conformity between the company and its employees in organizational commitment and job satisfaction [11]. Changes in organizational structure were formed to expand and speed up communication between superiors and employees. The enactment of structural changes by adding zones into 6 sections and there is a field coordinator in each zone. This is done to provide a more stable communication space, situation and working conditions. This change in structure can bring employees closer to their superiors. 
Changes to policies or regulations are made by adjusting the wishes of employees and the interests of the company. As the number of employees increases, the number of coordinators or managers in the field will increase and it is possible for all employees to get opportunities to get promotions. With the contract of PT Febri Dharma Mandiri at the Abdoel Moeloek Hospital, the hospital policy also applies to the company by getting supervision from the K3 team (occupational health and safety) and the PPI team (infection prevention and control) for the safety of all employees of PT Febri Dharma Mandiri when work.

By dividing it into 6 zones, it makes it easier for superiors to supervise and communicate with employees who are in each zone. With direct supervision every day, employees can directly ask their superiors related to work and get good answers and directions from their superiors directly. It also makes it easier for employees to get equipment and materials used in their work. With the fulfillment of work facilities and good communication between colleagues and superiors, it will improve the work atmosphere and can lead to normative commitment.

Changes in policy by adjusting the wishes of employees can also be seen in changes in salaries received by employees with a significant increase of $28 \%$. Provide training and theoretical learning that is used on the job to help employees succeed in competency tests to obtain licensed professional certification. With these policies that can benefit employees, it will make employees to consider the losses or gains that will be lost if they leave the company and allow the emergence of continuance commitment that will make employees stay to work at the company.

In 2020 by increasing the number of employees to a total of 178, the total turnover percentage decreased to $6 \%$. Based on what happened at PT Febri Dharma Mandiri, the author has several questions regarding the existing problems. Do job satisfaction and organizational commitment affect turnover intention?. As happened in 2020 , is increasing person organization fit in terms of job satisfaction and organizational commitment an important role in decreasing the turnover percentage?

\section{Research Method}

The research method used in this study is a quantitative method. This research also includes quantitative research that is correlational. The population in this study were all employees of PT Febri Dharma Mandiri, totaling 178 people. Based on the results of calculations [12] the Slovin formula, the number of samples that needed to be studied were 123 employees. The sampling method in this study used the method of determining the sample by simple random sampling and the value measurement technique used in this study was the Likert scale. The method used in this research is multiple linear analysis method using SPSS program.[13]

\subsection{Literature Review Job satisfaction}

Job satisfaction as an assessment of the perceived characteristics of the job, the work environment and the emotional experience gained in the job. Job satisfaction is also an assessment, attitude or feeling of an employee towards the work he does, and is related to factors such as type of work, work environment, relationships between co-workers, compensation, and social relations at work [14].

\section{Organizational commitment}

Organizational commitment is a degree or tool to see how far an employee identifies his involvement in the organization. In other words, organizational commitment is a process where organizational members are at the level of showing their attention to the organization, and organizational commitment can be seen in employees who are loyal to the organization and work wholeheartedly to help the organization achieve its goals and they will have loyalty to survive in the organization. [15] 


\section{Turnover Intention}

Turnover intention is a desire to move or leave the company, where the desire has not yet reached the stage of moving from one workplace to another or leaving the workplace. If the desire arises, it will be seen in the behavior of employees who begin to increase absenteeism, increase violations of work rules, have the courage to oppose or protest against superiors, and decrease employees' sense of responsibility in completing their work [16].

\section{Person Organization fit}

Person-organization fit can be said as the similarity of values, the similarity of goals and the compatibility between the needs of employees and the support found in the work environment, the compatibility between individual and organizational characteristics. This conformity can be realized if the organization has fulfilled the needs of its employees. The greater the level of person-organization fit that occurs, the higher the impact on the results desired by the company, including increasing job satisfaction, organizational commitment and decreasing the level of employees leaving [17].

\subsection{Hypotheses}

\section{Research Framework}

From the description above, the following research framework can be described:

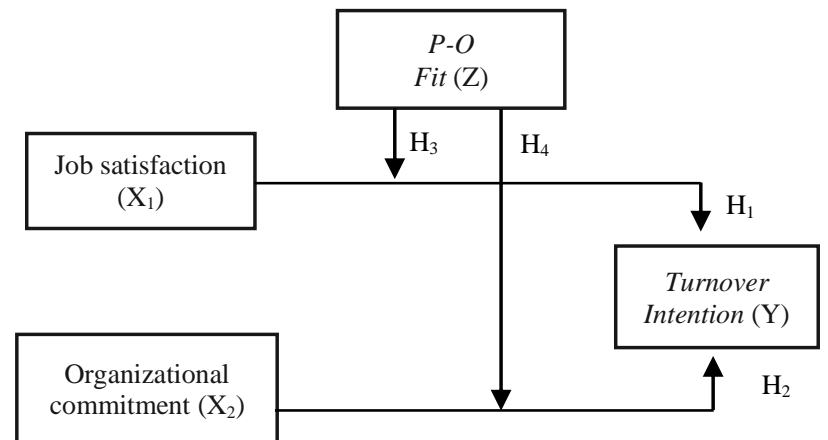

Figure 1 Research framework

Based on the theoretical basis, the following hypotheses can be formulated:

$\mathrm{H} 1$ : Job satisfaction (X1) has a negative and significant effect on turnover intention ( $\mathrm{Y}$ )

$\mathrm{H} 2$ : Organizational commitment (X2) has a negative and significant effect on turnover intention $(\mathrm{Y})$

$\mathrm{H} 3$ : Moderation of Person-organization fit $(Z)$ has a significant effect on the relationship between job satisfaction (X1) and turnover intention $(\mathrm{Y})$

$\mathrm{H} 4$ : Moderation of Person-organization fit $(Z)$ has a significant effect on the relationship between organizational commitment (X2) and turnover intention $(\mathrm{Y})$.

\section{Result and Discussion}

\subsection{Multiple Linear Regression Test}

Multiple linear regression analysis is done by specifying the equation. The results of the calculation of the values will be described as follows: 
Table2

Multiple Linear Regression Test Results Equation 1

Coefficients $^{\mathrm{a}}$

\begin{tabular}{|c|c|c|c|c|c|c|}
\hline \multirow[b]{2}{*}{ Model } & & \multicolumn{2}{|c|}{ Unstandardized Coefficients } & \multirow{2}{*}{$\begin{array}{c}\text { Standardized } \\
\text { Coefficients }\end{array}$} & \multirow[b]{2}{*}{ t } & \multirow[b]{2}{*}{ Sig. } \\
\hline & & $B$ & Std. Error & & & \\
\hline \multirow[t]{3}{*}{1} & (Constant) & 14.804 & .441 & & 33.605 & .000 \\
\hline & Kepuasan Kerja & -157 & .033 & -.278 & -4.728 & .000 \\
\hline & Komitmen Organisasi & .564 & .048 & .693 & -11.805 & .000 \\
\hline
\end{tabular}

a. Dependent Variable: Turnover Intention

$$
Y=14,804-0,157 X 1-0,564 X 2+e
$$

$Y=$ Turnover intention

$\beta o=$ Constant

$\mathrm{X} 1=$ Job satisfaction

$\mathrm{X} 2$ = Organizational commitment

$\beta 1=$ coefficientof variable $X 1$

$\beta 2=$ coefficientof variable $X 2$

The explanation of the regression equation above is as follows:

1. The constant value of 14,804 means that if the variables of job satisfaction and organizational commitment are not included in the study, the turnover intention of employees at PT Febri Dharma Mandiri still increases by $14.804 \%$.

2. The value of the coefficient $\beta 1$ has a value of -0.157 , which means that if the job satisfaction variable is increased even more (such as by increasing employee salaries, providing promotion opportunities, maintaining good communication between employees and superiors), the turnover intention rate at PT Febri Dharma Mandiri will decrease. of $0.157 \%$ with the assumption that other independent variables still have the same value.

3. The value of the coefficient 2 has a value of -0.564 which means that if the organizational commitment variable is increased even more (Providing jobs or tasks to employees the abilities and interests of the employee, providing adequate rewards or compensation in proportion to the employee's workload) Turnover intention at PT Febri Dharma Mandiri will decrease by $0.564 \%$ with the assumption that other independent variables have the same value.

Table3

Multiple Linear Regression Test Results Equation 2

\begin{tabular}{|c|c|c|c|c|c|c|}
\hline \multicolumn{7}{|c|}{ Coefficients $^{a}$} \\
\hline \multirow[b]{2}{*}{ Mode } & & \multicolumn{2}{|c|}{ Unstandardized Coefficients } & \multirow{2}{*}{$\begin{array}{c}\begin{array}{c}\text { Standardized } \\
\text { Coefficients }\end{array} \\
\text { Beta } \\
\end{array}$} & \multirow[b]{2}{*}{$t$} & \multirow[b]{2}{*}{ Sig. } \\
\hline & & $\mathrm{B}$ & Std. Error & & & \\
\hline 1 & (Constant) & 23.662 & 4.519 & & 5.236 & .000 \\
\hline & Kepuasan Kerja & .523 & .352 & .924 & 1.487 & .140 \\
\hline & Komitmen Organisasi & -2.407 & .515 & -2.959 & -4.678 & .000 \\
\hline & Person Organization fit & -.501 & .289 & -.771 & -1.732 & .086 \\
\hline & $\mathrm{X} 1 \star \mathrm{Z}$ & -.039 & .021 & -2.306 & -1.860 & .066 \\
\hline & $X 2^{\star} Z$ & .105 & .029 & 4.125 & 3.583 & .001 \\
\hline
\end{tabular}

a. Dependent Variable: Turnover Intention

$$
Y=23,662+0,523 X 1-2,407 X 2-0,501 Z-0,039 X 1 Z+0.105 X 2 Z+e
$$


Information :

$\mathrm{Y}=$ Turnover intention

Bo $=$ Constant

$\mathrm{X}_{1}=\mathrm{Job}$ satisfaction

$X_{2}=$ Organizational commitment

$Z$ = Person organization fit

$\beta 1=$ Coefficient of variableX1

$\beta 2=$ Coefficient of variable $X 2$

$\beta 3=$ Coefficient of variable $Z$

$\beta 4=$ Coefficient of variable $X 1^{\star} Z$

$\beta 5=$ Coefficient of variable $X 2^{*} Z$

$\mathrm{e}=$ Error of term (variable outside the model)

The explanation of the regression equation above is as follows:

1. The constant value of 23,662 means that if the variables of job satisfaction, organizational commitment, and moderation of person organization fit are not included in the study, the turnover intention of employees at PT Febri Dharma Mandiri still increases by $23.662 \%$

2. The coefficient value 1 has a value of 0.523 which means that if the job satisfaction variable is increased even more (such as by increasing employee salaries, providing promotion opportunities, maintaining good communication between employees and superiors), the turnover intention rate at PT Febri Dharma Mandiri will increase by $0.523 \%$ with the assumption that other independent variables have the same value.

3. The value of the coefficient 2 has a value of -2.407 which means that if the organizational commitment variable is increased even more (Providing jobs or tasks to employees [18] the abilities and interests of the employee, providing adequate compensation or compensation in proportion to the employee's workload) then the level of Turnover intention at PT Febri Dharma Mandiri will decrease by $2.407 \%$ with the assumption that other independent variables have the same value.

4. The value of the coefficient 3 has a value of -0.501 which means that if the person organization fit variable is increased even more (such as by improving communication between the company and employees, listening to the opinions and wishes of employees with the aim of improving or adding to the work system and regulations that employees want increase the suitability and compatibility between the company and its employees) then the turnover intention rate at PT Mandiri will decrease by $0.501 \%$ with the assumption that other independent variables still have the same value.

5. The coefficient value 4 has a value of -0.039 , which means that if the moderating variable is added to person organization fit between job satisfaction and turnover intention, it will reduce the effect of job satisfaction on turnover intention by $0.039 \%$ which will result in an increase in turnover intention with the assumption that other independent variables still have the same value.

6. The coefficient value 5 has a value of 0.105 , which means that if the moderating variable is added to person organization fit among organizational commitment to turnover intention, it will increase the effect of organizational commitment on turnover intention by $0.105 \%$ which will result in a decrease in turnover intention with the assumption that other independent variables remain have the same value.

\subsection{T test (Partial Test)}

The $t$ test is used to determine whether or not there is a partial effect of the independent variable on the dependent variable. Statistical analysis in this study uses multiple linear regression analysis, which is intended to test the truth of the research hypothesis. This test is by comparing the probability value or $p$-value (sig-t) with a significance level of 0.05 .

The results of the coefficient values in the t-test table and comparing the probability level of 0.05 with the significance value and comparing the $t$-count value with the t-table is 1.659 which is obtained from the t-table with n-k i.e. 106 and alpha 0.05 . The following is a discussion of the partial test between job satisfaction and organizational commitment to the turnover intention of PT Febri Dharma Mandiri. 


\section{a. The Effect of Job Satisfaction on Turnover Intention}

By looking at the table, it can be seen that the $t$ value of job satisfaction is -4.728 and the t table is 1.659 , this value indicates that the $t$ count $>t$ table $(4.728>1.659)$ and is negative. When viewed from the significance value of job satisfaction 0.000 is smaller than 0.05 so it can be concluded in accordance with Hypothesis 1 that the variable job satisfaction has a negative and significant effect on employee turnover intention.

\section{b. The Effect of Organizational Commitment on Turnover Intention}

By looking at the table, it can be seen that the t-count value of organizational commitment is 11.805 and the t-table is 1.659 , this value indicates that the $t$-count $>t$-table $(11.805>1.659)$ and is negative. When viewed from the significance value of organizational commitment 0.000 is smaller than 0.05 so it can be concluded in accordance with Hypothesis 2 that the organizational commitment variable has a negative and significant effect on employee turnover intention.

\subsection{Moderated Regression Anlysis (MRA)}

This study uses an interaction test to test the moderating variable in the form of person organization fit using Moderated Regression Analysis (MRA) [19]. (MRA) Moderated Regression Analysis aims to find out the results of hypothesis 3 and hypothesis 4 with the role of person organization fit as a moderating variable. MRA is a multiple linear regression test, where in the regression equation there is an element of interaction (multiplication of two or more independent variables).

The following results are the coefficient values in the t-test table and compare the probability level of 0.05 with the significance value and compare the t-count value with the t-table which is 1.982 obtained from the t-table with $n-k$ which is 105 and alpha 0.05 . The following is a discussion of the partial test of the moderating variable of person organization fit between job satisfaction and employee turnover intention. And the moderating variable is person organization fit between organizational commitment and employee turnover intention.

\section{a. The moderating effect of person organization fit between job satisfaction and turnover intention}

Based on the results of the interaction test or moderated regression analysis (MRA) in table 4.15 , it shows that the moderating variable $\mathrm{X} 1^{*} \mathrm{Z}$ has a $\mathrm{t}$-count value of -1.860 and a t-table of 1.982 , this value indicates that the value of $t$-count $<t$-table $(1.860<1.982)$ and negative value. When viewed from the significance value of $X 1{ }^{*} \mathrm{Z}$ of 0.066 , which is greater than 0.05 , it can be concluded by looking at Hypothesis 3 . That the moderating variable of person organization fit has no significant effect on the relationship between the variable job satisfaction and employee turnover intention.

\section{b. The moderating effect of person organization fit between organizational commitment and turnover intention}

Based on the results of the interaction test or moderated regression analysis (MRA) in table 4.15 , it shows that the moderating variable $X 2^{\star} Z$ has a $t$-count value of 3.583 and a t-table of 1.982 , this value indicates that the value of $t$-count $>t$-table $(3.583>1.982)$ and is worth positive. When viewed from the significance value of $X 2^{\star} Z, 0.001$ is smaller than 0.05 so it can be concluded by looking at Hypothesis 4. That the moderating variable of person organization fit has a significant effect on the relationship between organizational commitment variables and employee turnover intention.[20]

\section{Conclusion}

This study aims to determine the effect of job satisfaction and organizational commitment on turnover intention with person organization fit as a moderating variable on employees of PT Febri Dharma Mandiri. Respondents in this study amounted to 123 employees and data that can be processed amounted to 109 data. Based on the data that has been collected and the

The Effect Of Job Satisfaction And Organizational Commitment On Turnover Intention With Person Organization Fit As Moderator Variable (Eko Nur Pratama) 
tests that have been carried out on the problem using multiple linear regression models and MRA (Moderated Regression Anlysis). then the following conclusions can be drawn:

Based on a partial test that job satisfaction has a negative and significant effect on turnover intention with a significance value of 0.000 lower than 0.05 and a $t$ count $>t$ table $(4.728>$ 1.659). And the organizational commitment variable also has a negative and significant effect on turnover intention with a significance value of 0.000 lower than 0.05 and a $t$ count $>t$ table (11.805 > 1.659).

Based on the moderated regression analysis (MRA) test, the variable person organization fit has no significant effect on the relationship between job satisfaction and turnover intention with a $t$ count $<\mathrm{t}$ table $(1.860<1.982)$ which is negative, and has a significance value of 0.66 greater of 0.05 . Meanwhile, the variable person organization fit which moderates the relationship between organizational commitment and turnover intention is influential and significant with a significance value of 0.001 lower than 0.05 and a t count $>t$ table $(3.583>$ 1.982).

\section{References}

[1] M. Hidayat and F. Latief, "The influence of developing human capital management toward company performance (The evidence from developer companies in south Sulawesi Indonesia)," SEIKO J. Manag. Bus., vol. 2, no. 1, pp. 11-30, 2018.

[2] J. Nelissen, A. Forrier, and M. Verbruggen, "Employee development and voluntary turnover: Testing the employability paradox," Hum. Resour. Manag. J., vol. 27, no. 1, pp. 152-168, 2017.

[3] S. R. Hasibuan, M. Damanik, and H. I. Nasution, "Differences in Learning Models of Problem Based Learning and NHT Cooperative Type with Card Media Assistance to Student Learning Outcomes and Activities in Naming Chemical Compounds," J. Transform. Educ. Educ. Leadersh., vol. 1, no. 1, pp. 18-22, 2019.

[4] D. Mardhiyana and N. B. Nasution, "Kesiapan mahasiswa pendidikan matematika menggunakan e-learning dalam menghadapi era revolusi industri 4.0," in Seminar Nasional Pendidikan Matematika Ahmad Dahlan, 2019, vol. 6.

[5] N. N. Y. S. Lestari and N. W. Mujiati, "Pengaruh Stres Kerja, Komitmen Organisasi, Dan Kepuasan Kerja Karyawan Terhadap Turnover Intention." Udayana University, 2018.

[6] A. Agus and R. Selvaraj, "The mediating role of employee commitment in the relationship between quality of work life and the intention to stay," Empl. Relations Int. J., 2020.

[7] J. C. Wombacher and J. Felfe, "Dual commitment in the organization: Effects of the interplay of team and organizational commitment on employee citizenship behavior, efficacy beliefs, and turnover intentions," J. Vocat. Behav., vol. 102, pp. 1-14, 2017.

[8] F. Lia and H. Bambang, "Effect of job satisfaction and perception of work opportunities to turnover intention with organization commitment as intervening variables: the case of hotels in East Java, Indonesia," Russ. J. Agric. Socio-Economic Sci., vol. 68, no. 8, 2017.

[9] E. Goh and F. Okumus, "Avoiding the hospitality workforce bubble: Strategies to attract and retain generation $\mathrm{Z}$ talent in the hospitality workforce," Tour. Manag. Perspect., vol. 33, p. 100603, 2020.

[10] J. Buchan, A. Charlesworth, B. Gershlick, and I. Seccombe, "A critical moment: NHS staffing trends, retention and attrition," London Heal. Found., 2019.

[11] I. K. Raharjana et al., Journal of Information Systems Engineering and Business Intelligence: Volume 3 Number 2, Oktober 2017, vol. 3. Journal of Information Systems Engineering and Business Intelligence, 2017.

[12] S. L. Ratnasari and L. Lestari, "Effect of Leadership Style, Workload, Job Insecurity on Turnover Intention," Int. J. Innov. Creat. Chang., vol. 10, no. 2, pp. 1315-2201, 2020.

[13] M. H. A. Ong and F. Puteh, "Quantitative data analysis: Choosing between SPSS, PLS, and AMOS in social science research," Int. Interdiscip. J. Sci. Res., vol. 3, no. 1, pp. 14- 
25, 2017.

[14] M. A. Qureshi and K. Hamid, "Impact of supervisor support on job satisfaction: A moderating role of fairness perception," Int. J. Acad. Res. Bus. Soc. Sci., vol. 7, no. 3, pp. 235-242, 2017.

[15] B. Al-Jabari and I. Ghazzawi, "Organizational Commitment: A Review of the Conceptual and Empirical Literature and a Research Agenda.," Int. Leadersh. J., vol. 11, no. 1, 2019.

[16] R. L. Cowan, E. Clayton, and J. Bochantin, "Human resources as an important actor in workplace bullying situations: Where we have been and where we should go," Pathways Job-related Negat. Behav., pp. 477-494, 2021.

[17] M. H. Jin, B. McDonald, and J. Park, "Person-organization fit and turnover intention: Exploring the mediating role of employee followership and job satisfaction through conservation of resources theory," Rev. Public Pers. Adm., vol. 38, no. 2, pp. 167-192, 2018.

[18] H. Inegbedion, E. Inegbedion, A. Peter, and L. Harry, "Perception of workload balance and employee job satisfaction in work organisations," Heliyon, vol. 6, no. 1, p. e03160, 2020.

[19] I. G. A. A. O. Dewi and I. G. A. A. P. Dewi, "Corporate social responsibility, green banking, and going concern on banking company in Indonesia stock exchange," Int. J. Soc. Sci. Humanit., vol. 1, no. 3, pp. 118-134, 2017.

[20] R. Rostiana, "The Quality of Work Life Influence to Turnover Intention With PersonOrganization Fit and Organizational Commitment as Mediators.," Int. J. Econ. Manag., vol. 11, 2017. 